\title{
What Are the Implications of the Covid-19 Situation Now and in the Future on Rural Women in Agriculture in Nigeria
}

\author{
Adedayo, Temitayo Gbeminiyi \\ Establishments Department, Tai Solarin College of Education, Omu, Ijebu, PMB 2128, Ijebu-Ode, Ogun State \\ Sennuga, Samson Olayemi, Ph.D \\ School of Agriculture, Food and Environment, Royal Agricultural University, Stroud Road, Cirencester, \\ Gloucester, United Kingdom, GL76JS \\ Sennuga, Mabayoje Albert \\ Economics Department, School of Arts and Social Sciences, \\ Tai Solarin College of Education, Omu-Ijebu, PMB 2128, Ijebu-Ode, Ogun State
}

\begin{abstract}
The outbreak of Corona Virus Pandemic in Wuhan City in China and its eventual spread to other nations of the world including Nigeria has crippled the world economy including that of Nigeria which relied mainly on primary products. The unfortunate aspect of the pandemic is the fact that the Federal Government of Nigeria (FGN) has now diverted its scarce resources from the sector that served as the main stay of the economy to the health sector in an attempt to save life. The implication of this is the neglect of agricultural production at a very crucial period when pre and planting operations should be on-going. The consequential effect of this is shortage of essential food items in the market with rural women bearing the brunt. Currently in the country, price of essential staple food items has gone up astronomically as a result of the pandemic. In order to mitigate the effect of this pandemic, the paper suggests that rural women engaged in agriculture should be given access to micro loans via provision of financial and technical support to grassroots farmers/groups while new innovations and techniques such as farm mechanization, use of mini-planters, harvesters and other time-labour-saving equipment should be encouraged to serve as substitute to scarcity of farm labour.
\end{abstract}

Keywords: COVID-19, Implications, Rural Women, Agricultural Products and Technology

DOI: $10.7176 / \mathrm{JESD} / 11-10-18$

Publication date:May $31^{\text {st }} 2020$

\section{Introduction}

In late December 2019, a novel coronavirus (COVID-19) was identified as the cause of a significant number of human cases of a respiratory disease in China. The outbreak of the current pandemic virus was first detected in Wuhan City, which is a major domestic and international economic and transport hub in China. Within two months, the deadly virus has turned the whole world upside down. The first index case was reported in Nigeria in February, 2020 and as at $19^{\text {th }}$ April, 2020, the figure of infected persons/confirmed cases has increased to 627 with the Federal Government of Nigeria shutting down Ogun state, Lagos state and Federal Capital Territory. Many states of the federation have also been shut down to curtail the spread of the dreaded virus.

International Labour Organisation (2020) has estimated that full or partial lockdown measures now affect almost 2.7 billion workers, representing around $81 \%$ of the world's workforce, while the IMF projects a significant contraction of global output in 2020. COVID-19 is lurching the world economy towards a global recession, which will be strikingly different from past recessions. Emerging evidence on the impact of the pandemic suggests that women's economic and productive lives will be affected disproportionately and differently from men. Across the globe, women earn less, save less, hold less secure jobs and are more likely to be employed in the informal sectors. They have less access to social protections and are the majority of single-parent households. Their capacity to absorb economic shocks is therefore less than that of men.

There is no doubt in the fact that the corona virus pandemic has continue to take its toll in Nigeria with women being the more vulnerable to economic shocks arising from the crises occasioned by the outbreak of the coronavirus pandemic. More than 70 percent of rural population rely on subsistence farming. Particularly striking, however, is the fact that rural women, more than their male counterparts, take the lead in the agricultural sector, making up to 60-80 percent of labour force (Ogunlela, 2009). Rural women are key agents for development as they play a catalytic role towards achievement of transformational economic, environmental and societal changes required for sustainable development. They are majorly involved in agricultural activities such as planting, weeding, harvesting, processing and marketing as well as keeping some domestic animals and birds. Since the Government has asked people to stay at home whilst this is to curb movements to limit the transmission of COVID19 , these steps will no doubt have unintended consequences for the poorest and most vulnerable which are the women, especially those at the rural areas, majority of whom are farmers. There is no doubt that the current 
pandemic (COVID-19) ravaging the world has some implications on rural women. These implications are thus stated.

\section{Current implication of COVID -19 on Rural Women in Agriculture in Nigeria}

1. Disruption of Market Chain: The restrictions on the movement of goods and people have significant socio-economic repercussions on people's livelihoods, going beyond the direct impact on health, and affecting the most vulnerable groups. While these restrictions are necessary to limit the spread of a disease, they often lead to disruption of market chains and trade of agricultural products, with significant potential impacts on the populations that depend on them for their livelihoods and their food and nutrition security. In addition, the restriction of movement has impeded farmers' access to markets, curbing their productive capacities and hindering them from selling their produce, especially perishable items.

2. Increase in Price of Imported Agricultural Drugs: Many of the agricultural drugs used in poultry are imported to Nigeria from China. With the current pandemic CORONA Virus, these products could not be imported while the few drug sellers take advantage of the scarcity to hike prices by over $50 \%$. This will no doubt reduce the profit margin of women who are into poultry production.

3. Shortage/Reduction in Farm Work Force for Agricultural Operations: The outbreak of the pandemic coincided with the period of land preparation and clearing which are usually carried out by labourers mostly men. With the outbreak of the pandemic and restriction on movement, there is shortage of labour available for use by rural women for agricultural cultural practices especially pre-planting operation. In the case of food productions, as the coronavirus crisis unfolds, there are labour shortages due to morbidity and movement restrictions which are starting to impact on women processors and traders. There is limited access to farming activities which will result in less vehicular movement from one point to another. There is also disruption in the planting season as most farmers are supposed to be on their farms preparing their land for planting. There will be shortage of fertilizers, veterinary medicines and others which could affect agricultural production by rural women. In fact, some women farmers will be forced to reduce the size of their farm in response to the decline in the required labour force for pre-planting operations.

4. Reduction in Production and Increase in Prices of Goods

The current pandemic Virus (COVID-19) has made the Federal Government of Nigeria to shift attention and scarce resources from productive activities to funding the health sector, in a bid to save lives. Currently, Personal Protective Equipment, ventilators, ambulances, isolated centres and other emergency health expenditure are being made by all levels of government in Nigeria. This, in turn, could mean reduced food production which will cause the forces of demand and supply to bring about an increased in food price and increase in the number of people who cannot afford their daily meals. The rural women are the people that will bear the brunt. At the moment, a bag of rice is about $\$ 25,000$ while a bag of gari is about $\$ 7,000$ which will no doubt be unbearable for rural women.

5. Wastage of Farm Products and Loss/Reduction of Farmer's Income

Blockages to transport routes are particularly obstructive for fresh food supply chains and may also result in increased levels of food loss and waste. Fresh fish and aquatic products, which are highly perishable and therefore need to be sold, processed or stored in a relatively limited time are at particular risk. Transport restrictions and quarantine measures are likely to impede farmers' and fishers' access to markets, curbing their productive capacities and hindering them from selling their produce. Most of the relaxation centres where these products are in high demand have been temporarily banned with the social distance rule and reduction of number of people per gathering to 5 .

6. Food Crisis: With the current arrangement put in place by the Federal Government of Nigeria, with restriction on movement of persons and vehicles and quarantine measures which impede farmers movement and access to markets, reducing their productive capacities, hindering them from selling their product and seasonal labourers not available for farming operations, it is therefore, glaring that food shortage and invariably, food crisis is imminent.

\section{Future Implication of COVID -19 on Rural Women in Agriculture in Nigeria \\ 1. Low Demand for Agricultural Products}

Nigeria operates a largely mono- product economy solely dependent on crude oil. Past and even the present government had on many occasions mouthed the need to take the economy out of dependence on oil. The national budget was based on $\$ 57$ per barrel but with the crash in the oil price at the global market which is attributed to two major factors: the Coronavirus pandemic and the oil war between Saudi Arabia and Russia, the anticipated revenue from oil may not be attained as oil price currently hover between $\$ 10$ and $\$ 5$ per barrel. The revenue available for sharing amongst the three tiers of government will fall drastically and by implication, the allocation to each levels of government. The consequential effect of this is that some state governors may not be able to pay salary and once workers are not paid, their purchasing power will fall and this will also be extended to agricultural products. At the moment, poultry 
farmers are already experiencing glut due to restriction of movement and low purchasing power.

Increase in Hunger and Poverty level amongst Rural Women

Before the coronavirus hit the world, Nigeria had been designated as the poverty headquarters of the world, with some 87 million Nigerians, or around half of the country's population, thought to be living on less than $\$ 1.90$ a day. With current restriction of movement put in place by the Federal Government of Nigeria vis-à-vis the fall in Federal Government revenue, the implication of the fall in demand for agricultural product and the attendant wastage/spoilage of agricultural perishable products will reduce farmers and their standard of living will be low. Some farmers producing perishable items that even employ women as farm workers may be forced to disengage their staff when their product cannot get to the final consumers due to the restriction on movement.

3. Food Shortage: As a result of on-going pandemic ravaging the world, Nigeria inclusive, the number of available labour force for agriculture will reduce, national resources committed to agricultural development will fall and above all, the period which ought to have been devoted for pre-planting and planting operation has been used to restrict the movement of farmers, all these will reduce agricultural production which will lead to food shortage in the future.

4. Unemployment: The current pandemic virus has killed many people while many may not get over the attack of the virus on time. This will reduce the economically active part of the population available for industries, firms, service sector and agricultural sector, which is labour-intensive, inclusive. As at Tuesday, 21st April, 2020, The American President has suspended all immigration application to US in an attempt to retain the Job of Americans after the Corona pandemic. In Nigeria, the whole economy has been paralyzed across all sectors. Companies are not producing in the last one months while the service sector has been paralysed. With the crash in the price of oil in the international market to $\$ 3 \mathrm{pb}$ as at Tuesday, 21st April, 2020, future job loss is imminent.

5. Social Menace: A hungry man is an angry man. With the restriction on movement, people cannot go out to make out a living especially daily income earners. To make the situation worse, the Government is not doing enough to provide palliative to the poor, aged, vulnerable and daily income earners while people read on pages of newspaper and social media of distribution of billions of naira to Nigerians without same getting to the target audience and this has resulted to hunger and frustration. The consequence of this is that young and agile youth that cannot fend for themselves and their families will take to social menace like stealing and armed robbery. In Lagos and Ogun States where the lockdown is in operation, residence of these States have constituted themselves into Vigilante Groups to checkmate the activities of the men of the underworld terrorising them most of whom are demanding for money and food items from their target audience.

\section{Conclusion and Recommendations}

There is no doubt that the current CORONA Virus pandemic ravaging the world has devastating effect on agricultural production with majority of the burden on the rural women engaged in farming. To mitigate the effect of these pandemic on rural women engaged in agriculture, it is suggested that rural women in agriculture should be given access to micro loans via provision of financial and technical support to grassroots farmers/groups. The Achor Borrowers Programme of Ogun State Government where soft loans, agricultural inputs (such as feed, seeds, fertilizers, herbicides, pesticides, etc) and clearing of farmland is done by the state government using bulldozer is a step in the right direction. New innovations and techniques such as farm mechanization, use of mini-planters, harvesters and other time-labour-saving equipment should be encouraged. This will be a substitute to scarcity of farm labour. Other ways out of the challenges are:

1. The government needs to immediately identify key players in the food chain, track levels of food availability and distribution as this would require better linkages between users and producers.

2. There is also the need for farm camps where only people working on the farms are isolated adding that the logistics can be worked out with drop offs and pick-ups.

3. This is the time when digital agriculture can be harnessed and utilized to the fullest advantage such that digital technologies can be deployed to ensure that women across Nigeria will continue to have access to information that will help with the production of food and activities along the value chain.

4. The Federal government of Nigeria should spontaneously put in place policy directive that will facilitate the movement of farmers, agricultural workers, vehicles conveying agricultural produce and possibly classify them as priority workers as it is done for health workers. This will not only ease their movement but also go a long way to boost agricultural production and ultimately reduces food shortages that may occur in future.

5. In order to ensure unhindered production of agricultural produce amidst the outbreak of COVID-19, the various States Government across the country, through the Ministry of Health, should put in place necessary measures to contact farmers on the field to educate them on the virus (health-talk) as related to 
social distancing, hygiene, make available face masks and sanitizers and possibly make arrangements for accommodation in the farms (especially where farm settlement exist).

\section{References}

Ogunlela Yemisi I. and Aisha A. Mukhtar, 2009. Gender Issues in Agriculture and Rural Development in Nigeria: the Role of Women. Humanity \& Social Sciences Journal 4 (1) pp19-30.

http://www.isiswomen.org/downloads/wia/wia-2009-1/1wia09_00aFeatures_Karl.pdf 